\title{
NILAI-NILAI KARAKTERISTIK DALAM TEKS SASTRA THE HISTORY OF THE LIFE OF AJAMILA
}

\author{
Ni Ketut Dewi Yulianti \\ Institut Seni Indonesia (ISI) Denpasar \\ E-mail: dewiyulianti@isi-dps.ac.id
}

\begin{abstract}
Abstrak
Tulisan ini mengulas tentang teks sastra yang berjudul The History of The Life of Ajamiladengan fokus analisis pada nilai-nilai karakter yang terkandung di dalamnya. Tulisan ini dapat menjadi referensi bagi anak didik dan tenaga pengajar baik di tingkat dasar, menengah, dan pendidikan tinggi. Selain nilai-nilai karakter yang terdapat dalam teks, dibahas pula hubungan nilai-nilai karakter tersebut dengan pendidikan nasional. Hal ini sangat signifikan dan perlu untuk diteliti, mengingat saat ini banyak terjadi kemerosotan karakter anak bangsa dan juga permasalahan kebangsaan, seperti bergesernya nilai etika dalam kehidupan berbangsa dan bernegara, sekalipun telah ditetapkan bahwa pendidikan karakter adalah bagian utama dari pendidikan nasional. Dengan analisis nilai-nilai karakter dalam teks tersebut serta hubungannya dengan pendidikan nasional, maka nilai-nilai etika dalam kehidupan berbangsa dan bernegara akan dapat ditingkatkan, karena nilai-nilai karakter yang ada dalam teks tersebut dapat dengan mudah dijelaskan dan dipahami. Secara teoritis, tulisan ini dapat memberikan pemahaman tentang teks sastra yang bertema religi, terutama mengenai amanat yang terkandung di dalamnya. Secara praktis, tulisan ini dapat memberikan kontribusi bagi dunia pendidikan sehingga dapat membantu dalam meningkatkan keberhasilan pendidikan nasional, mengingat pendidikan karakter sudah menjadi bagian dari pendidikan nasional di Indonesia.
\end{abstract}

Kata kunci: Nilai-Nilai Karakter, Pendidikan Nasional,Teks Religi

\section{PENDAHULUAN}

Pendidikan karakter merupakan kebutuhan yang sangat signifikan dewasa ini mengingat pendidikan karakter merupakan upaya perwujudan amanat Pancasila dan pembukaan UUD 1945 yang dilatarbelakangi oleh realita permasalahan kebangsaan saat ini, seperti bergesernya nilai etika dalam kehidupan berbangsa dan bernegara. Hal ini sangat relevan dengan fungsi dan tujuan pendidikan nasional, seperti yang dijabarkan dalam Undang-Undang Republik Indonesia Nomor 20 Tahun 2003. Di sini disebutkan bahwa Sistem Pendidikan Nasional/UUSPN berfungsi untuk mengembangkan dan membentuk watak serta peradaban bangsa yang bermartabat dalam rangka mencerdaskan kehidupan bangsa, bertujuan untuk berkembangnya potensi peserta didik agar menjadi manusia yang beriman dan bertakwa kepada Tuhan Yang Maha Esa, berakhlak mulia, sehat, berilmu, cakap, kreatif, mandiri, dan menjadi warga negara yang demokratis serta bertanggung jawab (cf. Dewi Yulianti, 2016:6).

Teks sastra The History of The Life of Ajamila terdapat dalam kitab Srimad Bhagavatam skanda 6 Bab 1. Teks ini dapat dijadikan sebagai sumber pembelajaran dalam pendidikan karakter, karena teks ini mengandung nilai-nilai moral yang dapat dijadikan pedoman dalam pendidikan karakter. Dengan analisis nilai-nilai karakter dalam teks tersebut serta hubungannya dengan pendidikan nasional, maka nilai-nilai etika dalam kehidupan berbangsa dan bernegara akan dapat ditingkatkan, karena nilai-nilai karakter yang ada dalam teks tersebut dapat dengan mudah dijelaskan dan dipahami.

Berdasarkan uraian di atas, ada dua pokok bahasan yang diulas dalam paper ini, yaitu (a) nilanilai karakter yang terdapat dalam teks The History of The Life of Ajamila dan (b) hubungan nilai-nilai karakter tersebut dengan pendidikan nasional.

\section{METODOLOGI}

Penelitian ini menggunakan metode deskriptif kualitatif, yang mencakup tiga tahapan, yakni (1) tahap pengumpulan data, (2) tahap analisis data, dan (3) tahap penyajian hasil analisis. Objek penelitian ini berupa teks berbahasa Inggris "The History of the Life of Ajamila". Data yang berupa nilai-nilai karakter baik positif dan negatif dalam teks dikumpulkan dan dianalisis untuk menentukan hubungannya dengan pendidikan nasional.

Hasil analisis disajikan secara deskriptif. Penelitian ini lebih menekankan pada kegiatan mengumpulkan dan mendeskripsikan data 
kualitatif, sehingga penelitian ini dapat disebut penelitian deskriptif kualitatif. Penelitian kualitatif yang menekankan pada makna, lebih memfokuskan pada data kualitas dengan analisis kualitatifnya (Sutopo, 2004:48).

\section{PEMBAHASAN}

\section{Nilai-Nilai Karakter dalam Teks The History of The Life of Ajamila}

Teks sastra The History of The Life of Ajamila terdapat dalam kitab Srimad Bhagavatam skanda 6Bab 1. Teks ini dapat dijadikan sebagai sumber pembelajaran dalam pendidikan karakter. Sebelum mengulas nilai-nilai karakter yang terdapat di dalamnya, maka perlu dijelaskan alur cerita dari teks tersebut. Adapun alur cerita dari teks tersebut adalah sebagai berikut.

Teks ini menceritakan tentang Ajamila seorang laki-laki yang dilahirkan disebuah kota yang dikenal sebagai Kanyakubja dan menikah dengan seorang prostitusi sehingga dia kehilangan sifat-sifat kebrahmanaannya karena pergaulannya dengan wanita tersebut. Ajamila selalu membuat masalah dengan orang lain. Merampok, menipu dan mencuri milik mereka. Dengan cara demikian dia menghidupi dan memelihara anak-anak dan istrinya. Walaupun Ajamila lahir dari ayah seorang brahmana yang sangat ketat mengikuti prinsipprinsip darma seperti tidak makan daging (daya), tidak melakukan hubungan sex yang menyimpang (saucam), tidak mabuk-mabukan (tapa), dan tidak berjudi (satya), namun demikian dia jatuh cinta dengan seorang prostitusi sehingga dia kehilangan kualitas yang baik dalam dirinya. Tatkala seseorang meninggalkan prinsip-prinsip yang sesuai dengan kitab suci, dia akan menyibukkan dirinya dalam kegiatan yang penuh dosa.

Prinsip-prinsip aturan kitab suci menempatkan seseorang dalam standar kehidupan manusia yang sesungguhnya. Tetapi, jika prinsipprinsip aturan tersebut ditinggalkan, maka manusia akan jatuh ke dalam kehidupan yang penuh dengan hayalan atau maya. Jika ingin maju dalam kehidupan spiritual, manusia harus mengikuti prinsip-prinsip aturan dan membebaskan diri dari kesalahan kehidupan masa lampau dan masa sekarang. Hanya orang yang bebas dari segala jenis reaksi kegiatan yang berdosa dan menyibukkan dirinya dalam kegiatan yang saleh akan sepenuhnya bisa mengerti tentang Tuhan. Mereka yang bertindak dalam kegiatan yang penuh dosa dan begitu terikat akan kenyamanan secara badan tidak akan bisa berada dalam keinsafan diri yang rohani.

Kesalahan dari hubungan yang tidak benar dengan lingkungan akan menghancurkan kualitas dari sifat-sifat baik dalam diri seseorang. Ajamila meninggalkan segala jenis prinsip-prinsip aturan akibat pergaulannya dengan seorang prostitusi. Dia menjadi seorang penipu dan pencuri. Seseorang yang bertidak tanpa dilandasi dengan kejujuran akan mendapat hukuman. Dia boleh lepas dari hukum raja atau pemerintah, tapi dia tidak bisa lepas dari hukum Tuhan. Kitab suci menyatakan bahwa orang yang seperti itu sedang menipu kebahagiaannya sendiri.

Ajamila menjadi orang yang sangat berdosa dalam hidupnya. Dia menghidupi keluarganya dengan cara yang penuh dosa. Ajamila memiliki sepuluh anak dan anak yang paling kecil diberi nama Narayana (nama lain Sri Wisnu). Dia sangat menyayangi putra bungsunya dan bahkan sangat terikat dengannya. Dia tidak bisa berpisah sesaatpun dari anaknya yang paling kecil ini. Pada saat kematiaan menjemputnya dia selalu memanggil nama Narayana sehingga para Wisnuduta yang cemerlang datang menjemputnya. Semestinya orang yang dalam hidup yang penuh dosa selalu ditangani oleh para Yama-duta yang sangat menyeramkan dan menakutkan. Karena Ajamila selalu memanggil nama Narayana, yang datang menjemputnya adalah para Wisnu-duta. Itulah kekuatan pengucapan nama suci Tuhan, yang bisa membebaskan orang yang sangat berdosa sekalipun dari kehidupan neraka

\section{Nilai-nilai karakter}

Nilai-nilai karakter yang ditemukan dalam teks The History of the Life of Ajamila yaitu adalah sebagai berikut.

\section{Pergaulan}

Pergaulan sangat penting dalam membentuk karakter mental yang baiksehingga dengan mental yang baik seseorang akan berpikir, berkata dan bertindak dengan baik. Jika seseorang mendapatkan pergaulan yang buruk dia akan kehilangan kualitas baik dalam dirinya dan mewujudkan tindakan yang buruk, karena dalam diri seseorang selalu ada sifat baik dan sifat buruk.

\section{Disiplin}

Berdisiplin diri sangat penting dalam kehidupan untuk bisa belajar tunduk hati dalam 
mematuhi dan menghormati aturan dan peraturan.Mematuhi aturan dan peraturan yang ada dalam kitab suci sangat penting agar dapat terhindar untuk bertindak dalam kegiatan yang berdosa, karena kitab suci merupakan sumber kebenaran dari hukum Tuhan.

\section{Kejujuran (satya)}

Kejujuran sangat diperlukan untuk menuju sifat-sifat kebaikan dalam kehidupan ini. Tanpa ada kejujuran, manusia selalu menjauh dari sifatsifat kebaikan, dan dekat dengan sifat-sifat menipu, mencuri, merampok, korupsi dan dengan menghalalkan segala cara diluar etika dan moral.

\section{Kasih sayang (daya)}

Kasih sayang sangat diperlukan dalam menuju sifat yang harmonis. Tanpa ada kasih sayang tidak akan ada kesimbangan. Karena dengan adanya kasih sayang seseorang tidak akan mengeluarkan kata-kata kebencian, fitnah dan penghinaan, tidak akan ada pembunuhan dan menyakiti mahluk lain sehingga terwujud dalam bentuk tri hita karana, yaitu hubungan harmonis dengan mahluk hidup, dengan lingkungan dan dengan Tuhan sebagai Sang Pencipta. Karena dengan kasih sayang keserasian dan keharmonisan akan terwujud.

\section{Kesederhanaan (tapa)}

Kesederhanaan sangat diperlukan untuk mencapai kedamaian dalam hidup, karena tanpa kesederhanaan seseorang akan selalu mengejar keinginannya yang tidak ada batasnya. Karena pengertian kesederhanaan (tapa) adalah kita membatasi keinginan didalam mencapai kenikmatan indria-indria material.

\section{Kesucian (saucam)}

Segala tindakan dan kegiatan yang dilandasi oleh aturan kitab suci disebut kesucian. Bertindak untuk mengejar kenikmatan material sudah tidak dilandasi dengan aturan kitab suci, sehingga mengejar kenikmatan material tanpa batas. Dalam kitab SrimadBhagavatam dijelaskan bahwa kenikmatan tertinggi dalam kehidupan material adalah hubungan sexual. Dan hubungan sexual yang tidak sah (ellicit sex) akan menghancurkan nilai kesucian tersebut.

\section{Pelayanan Bhakti}

Sebelum diuraikan mengenai bakti, perlu dipahami tentang keinsafan diri. Keinsafan diri artinya memahami bahwa kita bukanlah badan material ini, kita adalah jiwa kehidupan (spirit soul) dan kita adalah bagian dan percikan dari Tuhan yang bersifat kekal, yang mana kedudukan dasar kita adalah pelayan Tuhan yang kekal. Jadi hubungan antara Tuhan dengan jiwa ini disebut dengan bakti. Karena kita tahu bahwa kita adalah jiwa yang merupakan bagian dan percikan dari Tuhan, kedudukan dasar kita yang sesungguhnya adalah pelayan Tuhan yang kekal, sehingga tujuan hidup kita yang sesungguhnya adalah kembali kepada Tuhan. Setiap orang seharusnya memiliki kewajiban untuk bertindak melayani dan mencintai Tuhan, dengan demikian akan mencapai kedamaian hidup yang akan bermuara dalam kebahagiaan. Karena tidak mungkin orang mencapai kebahagiaan tanpa ada kedamaian dalam hidupnya.

\section{Hubungan Nilai-Nilai Karakter dalam Teks dengan Pendidikan Nasional}

Dengan memberikan pergaulan atau pengajaran yang baik terhadap anak didik maka akan terwujud sifat-sifat baik dalam diri mereka. Untuk bisa mengembangkan kualitas yang baik, sehingga tidak ada kesempatan sifat-sifat buruk tumbuh dan berkembang dalam diri mereka, merupakan hal yang sejalan dengan tujuan pendidikan nasional yaitu mengembangkan dan membentuk watak dan peradaban bangsa yang bermartabat dalam rangka mencerdaskan kehidupan bangsa.

Berdisiplin diri adalah sangat penting bagi seseorang karena mulai belajar untuk mencintai dirinya, karena jika sesorang mulai disiplin dalam hidupnya berarti dia mulai mencintai dirinya. Karena dari mulai mencintai dirinya seseorang akan mengembangkan cintanya terhadap keluarga, masyarakat, bangsa, negara dan Tuhan. Wujud cinta terhadap masyarakat, bangsa, negara dan Tuhan adalah dengan menghormati dan mentaati aturan dan peraturan yang telah ditetapkan oleh negara dan kitab suci. Hal ini sesuai dengan tujuan pendidikan nasional yaitu membentuk watak yang mulia.

Kejujuran (satya), kasih sayang (daya), kesederhanaan (tapa) dan kesucian (saucam) mewujudkan seseorang dalam sifat-sifat rohani sehingga bisa membangun hubungan menuju pelayanan bakti kepada Tuhan Yang Maha Esa. Hal ini sangat sesuai dengan tujuan pendidikan nasional yaitu mengembangkan potensi anak didik 
yang menjadi manusia yang beriman dan bertakwa kepada Tuhan Yang Maha Esa.

Pelayanan bakti merupakan hubungan antara Tuhan dengan jiwa yang dilandasi dengan cinta kasih, karena hubungan ini tidak terkontaminasi oleh sifat-sifat alam material dan kedudukannya murni, sehingga dapat mewujudkan kebahagiaan yang rohani.

Fondasi dari pendidikan karakter yang sesungguhnya adalah self-realization (keinsafan diri). Apabila seseorang tidak memiliki selfrealization (keinsafan diri), ia akan berada dalam keinsafan material yang artinya bahwa ia menganggap dirinya adalah badan material, yang sepenuhnya berada di bawah kendali sifat keakuan palsu (false ego). Sifat keakuan palsu ini cendrung mengarahkan seseorang menuju pada kepuasan indria material, yang mana dirinya akan dikuasai oleh sifat-sifat nafsu, loba, dan kemarahan dan menjauhkannya dari sifat rendah hati. Hal ini merupakan pemicu awal kemerosotan moral, yang akan menjauhkannya dari sifat kejujuran dan rasa tunduk hati, sehingga tidak akan bisa mengembangkan karakter yang baik sesuai dengan tujuan pendidikan nasional (Dewi Yulianti \& Putra Yadnya, 2016:354).

Pendidikan nasional dimaksudkan untuk mengembangkan dan membentuk watak serta peradaban bangsa yang bermartabat dalam rangka mencerdaskan kehidupan bangsa, bertujuan untuk berkembangnya potensi peserta didik agar menjadi manusia yang beriman dan bertakwa kepada Tuhan Yang Maha Esa, berakhlak mulia, sehat, berilmu, cakap, kreatif, mandiri, dan menjadi warga negara yang demokratis serta bertanggung jawab. Hubungan nilai-nilai karakter yang terdapat dalam teks dengan pendidikan nasional adalah sangat erat, bahwa nilai-nilai karakter yang dimiliki Ajamila yang karena pergaulan dengan karakter kurang baik, membuat sifat-sifat buruk menguasainya. Namun, walaupun telah terlanjur dipengaruhi oleh sifat buruk, ketika Ajamila menyerukan nama Tuhan (Narayana), Tuhan mengampuninya, dan memberikan kesempatan kedua untuk kembali menjadi karakter mulia yang sesuai dengan ajaran Tuhan.

\section{SIMPULAN}

Dari uraian pada bagian pembahasan di atas, maka dapat disimpulkan hal-hal sebagai berikut.

(1) Nilai-nilai karakter yang terdapat dalam teks The History of The Life of Ajamila bahwa pergaulan adalah sangat penting untuk diperhatikan karena untuk bisa mengembangkan karakter yang baik maka diperlukan pergaulan yang baik. Berdisiplin diri akan membentuk keyakinan diri sehingga kita bisa menghormati aturan dan peraturan kitab suci, untuk dapat mengembangkan sikap-sikap yang tidak melanggar normanorma sehingga terhindar dari prilaku yang berdosa. Kejujuran, kasih sayang, kesederhanaan dan kesucian adalah sifat-sifat mulia yang mewujudkan seseorang dalam keinsafan diri, sehingga dapat mengenali siapa dirinya, siapa Tuhan dan bagaimana hubungan antara jiwa dengan Tuhan, dan bagaimana seharusnya bertindak menurut kedudukannya. Pelayanan bakti merupakan hubungan cinta kasih dengan Tuhan Yang Maha Esa yang tidak dipengaruhi oleh sifatsifat alam material seperti satvam, rajas dan tamas.

(2) Hubungan nilai-nilai karakter yang terdapat dalam teks dengan pendidikan nasional sangatlah erat, karena semua karakter dalam teks seperti pergaulan yang baik, disiplin diri, kejujuran, kasih sayang, kesederhanaan, kesucian dan pelayanan bakti semuanya sejalan dengan tujuan pendidikan nasional.

\section{DAFTAR PUSTAKA}

Dewi Yulianti, N.K.\& Putra Yadnya, IB. 2016. Self-Realization sebagai Fondasi Pendidikan Nasional. Prosiding Seminar Nasional Asosiasi Tradisi Lisan. Denpasar: 29-30 Juli.

Dewi Yulianti, N.K.2016. "Aspek Stilistika dalam Teks Srimad Bhagavatam: Kajian Terjemahan dari Bahasa Inggris ke Bahasa Indonesia" (disertasi). Denpasar: Program Studi Linguistik, Program Pascasarjana, Universitas Udayana.

Kemendiknas. 2011. Panduan Pelaksanaan Pendidikan Karakter. Badan Penelitian dan Pengembangan Pusat Kurikulum dan Perbukuan. Jakarta.

Prabhupada, A.C.1993. Srimad Bhagavatam. Sixth Canto(English). Los Angeles: The Baktivedanta Book Trust.

Sutopo, H.B. 2002. Metodologi Penelitian Kualitatif: Dasar Teori dan Terapannya dalam Penelitian. Surakarta: Sebelas Maret University Press. 